\title{
PROSPECTS FOR THE USE OF ALTERNATIVE FUELS AND ENERGY BY ROAD TRANSPORT IN RUSSIA
}

\author{
ALLA GOLUBEVA \& ELENA MAGARIL \\ Department of Environmental Economics, Ural Federal University, Russia
}

\begin{abstract}
Road transport is one of the main consumers of petroleum products and sources of air pollution. In the conditions of Russia's fast-growing vehicle fleet, it is necessary to develop and implement effective measures to reduce the consumption of scarce oil fuels and stimulate the use of alternative eco-friendly fuels. The aim of this work is to assess the prospects for the use of alternative fuels and energy by cars in Russia. This paper outlines the main ways of reducing the gasoline and diesel fuel consumption by road transport, including the use of the motor fuel alternative types. As the most promising direction of alternative energy development in the road transport sector regarding Russia's conditions, a transition to gas-cylinder fuel is proposed. This study presents the main problems of road transport gasification and the ways to solve them. The effective actions in the selected fields will reduce the consumption of scarce fuel and energy resources and enable improvement of the environmental situation in megalopolises.

Keywords: alternative fuels and energy, motor transport, liquefied petroleum gas, compressed natural gas, liquefied natural gas, traditional motor fuel, transport gasification.
\end{abstract}

\section{INTRODUCTION}

At the present stage of society development, in the conditions of industrial production volumes and the world's vehicle-amount growth, the depletion of fossil fuels is proceeding at high rates. The burning of traditional motor fuel by cars causes significant damage to the environment [1]-[3]. The reduction of consumption of scare fuels of petroleum origin by road transport is one of the priority problems of society's sustainable development.

Considerable attention is paid to research on the possibility of improving environmental sustainability and the energy efficiency of vehicles [4]-[8].

Liquefied petroleum gas (LPG) [9]-[12], compressed natural gas (CNG) [4], [6]-[10], [13]-[17] and liquefied natural gas (LNG) [2], [11], [12] are environmentally friendly alternatives to traditional liquid motor fuels, and it is advisable to expand their use.

Meanwhile, there is currently no systematic approach to reducing the consumption of traditional motor fuels by expanding the use of alternative fuels by the fleet. This leads to the irrational over-consumption of petroleum origin fuels, inhibits the development of the alternative motor fuel market, and worsens the environmental situation.

Thus, it is necessary to develop and implement mechanisms for the optimal use of oil origin fuels, to stimulate the development of alternative motor fuels in order to create sustainable, ecologically balanced economic development that takes into account the interests of the future generations.

\section{THE THREAT OF THE FUEL AND ENERGY RESOURCES CONSUMPTION GROWTH}

The modern level of civilization development is characterized by a rapid growth of the Earth's population (Table 1) and its ever growing need for exhaustible fuel and energy resources. An extensive scenario for the world energy development leads to the aggravation of the socio-economic and environmental problems, which requires the effective actions to shift to rational energy consumption. 
Table 1: The Earth's population dynamics, mln. people*.

\begin{tabular}{|l|c|c|c|c|c|c|c|c|}
\hline Region & $\mathbf{1 9 5 0}$ & $\mathbf{1 9 7 0}$ & $\mathbf{1 9 9 0}$ & $\mathbf{2 0 1 0}$ & $\mathbf{2 0 1 5}$ & $\mathbf{2 0 3 0}$ & $\mathbf{2 0 5 0}$ & $\mathbf{2 1 0 0}$ \\
\hline World including: & $\mathbf{2 , 5 2 5}$ & $\mathbf{3 , 6 8 2}$ & $\mathbf{5 , 3 1 0}$ & $\mathbf{6 , 9 3 0}$ & $\mathbf{7 , 3 4 9}$ & $\mathbf{8 , 5 0 1}$ & $\mathbf{9 , 7 2 5}$ & $\mathbf{1 1 , 2 1 3}$ \\
\hline Africa & 229 & 366 & 632 & 1,044 & 1,186 & 1,679 & 2,478 & 4,387 \\
\hline Asia & 1,394 & 2,120 & 3,202 & 4,170 & 4,393 & 4,923 & 5,267 & 4,889 \\
\hline Europe & 549 & 657 & 721 & 735 & 738 & 734 & 707 & 646 \\
\hline L. America & 169 & 288 & 447 & 600 & 634 & 721 & 784 & 721 \\
\hline North America & 172 & 231 & 281 & 344 & 358 & 396 & 433 & 500 \\
\hline Australia, etc. & 13 & 20 & 27 & 36 & 39 & 47 & 57 & 71 \\
\hline
\end{tabular}

*Based on the data from the United Nations [18], [19].

In 2017 , the primary energy consumption in the world was 13.5 billion TOE. The main energy resources consumers are China - 3.1 billion TOE $(23.2 \%$ of total energy consumption), the USA -2.2 billion TOE (16.5\%), and India -0.75 billion TOE (5.5\%). Russia occupies the fourth place, consuming 698.3 million TOE of the primary energy, which is equal to $5.2 \%$ of the total global consumption [20], [21].

Over the past 50 years, the primary energy consumption has increased by 3.7 times (Fig. 1). High rates of growth in fuel and energy resources consumption require the adoption of effective solutions in the field of their rational use and alternative energy development.

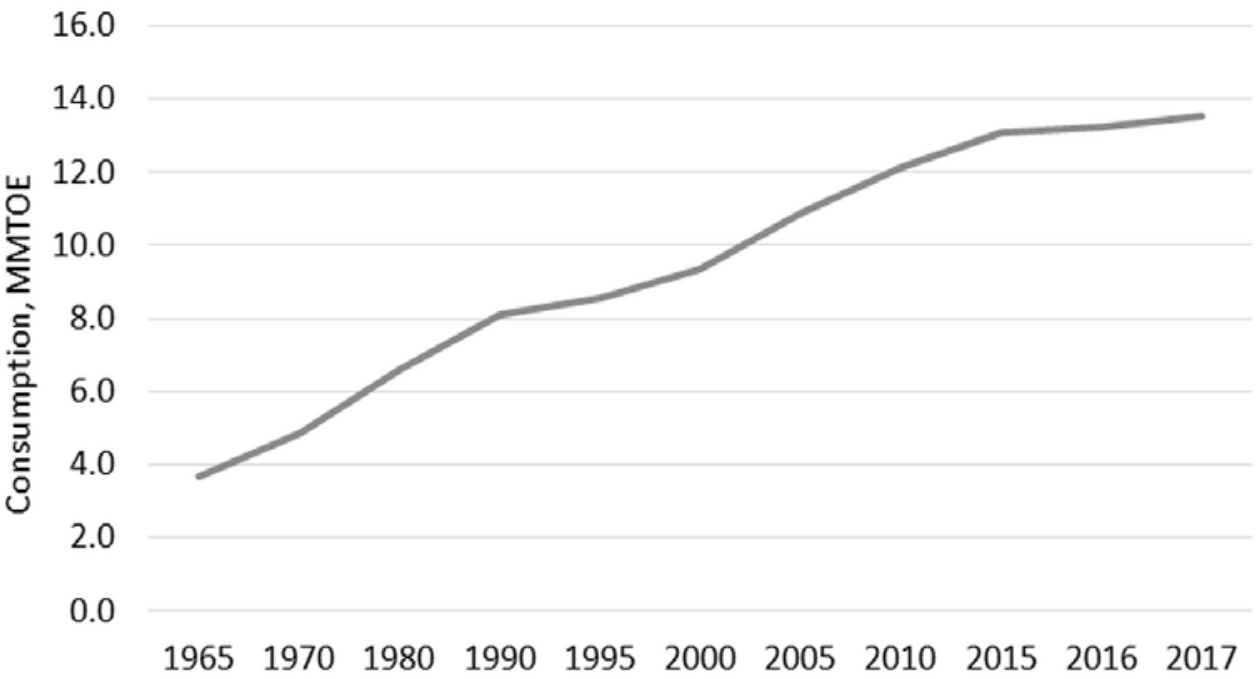

Figure 1: World primary energy consumption dynamics (based on data from BP [20], [21]).

\section{THE ROLE OF THE ROAD TRANSPORT IN THE REDUCTION OF FUEL AND ENERGY RESOURCES CONSUMPTION}

During the last 100 years, oil has been playing a central role in the world balance of energy consumption. In 2017, the share of oil in the total energy consumption was $34.2 \%$, coal $-27.6 \%$, natural gas $-23.4 \%$, while the total contribution of nuclear energy, hydropower and renewable energy sources was only $14.8 \%$ (Table 2) [20], [21]. 
Table 2: Energy resources consumption in 2017, MMTOE.

\begin{tabular}{|c|c|c|c|c|c|c|c|}
\hline \multirow[b]{2}{*}{ Region } & \multicolumn{6}{|c|}{ Energy resources } & \multirow{2}{*}{$\begin{array}{c}\text { Total } \\
\text { consumption }\end{array}$} \\
\hline & Oil & $\begin{array}{c}\text { Natural } \\
\text { gas }\end{array}$ & Coal & $\begin{array}{c}\text { Nuclear } \\
\text { energy }\end{array}$ & $\begin{array}{l}\text { Hydro- } \\
\text { power }\end{array}$ & $\begin{array}{c}\text { Renewable } \\
\text { energy }\end{array}$ & \\
\hline China & 608 & 207 & 1,893 & 56 & 262 & 107 & 3,132 \\
\hline USA & 913 & 636 & 332 & 192 & 67 & 95 & 2,235 \\
\hline India & 222 & 47 & 424 & 8 & 31 & 22 & 754 \\
\hline $\mathrm{RF}$ & 153 & 365 & 92 & 46 & 41 & 0.3 & 698 \\
\hline World total & 4,622 & 3,156 & 3,731 & 596 & 919 & 487 & 13,511 \\
\hline
\end{tabular}

The main consumers of petroleum are transport, industry, energy production, and other sectors. Within that, the priority role is taken by transport (Fig. 2). The main role of transport in oil consumption in the long term is confirmed by the medium- and long-term forecasts made by the BP and the International Energy Agency (IEA).
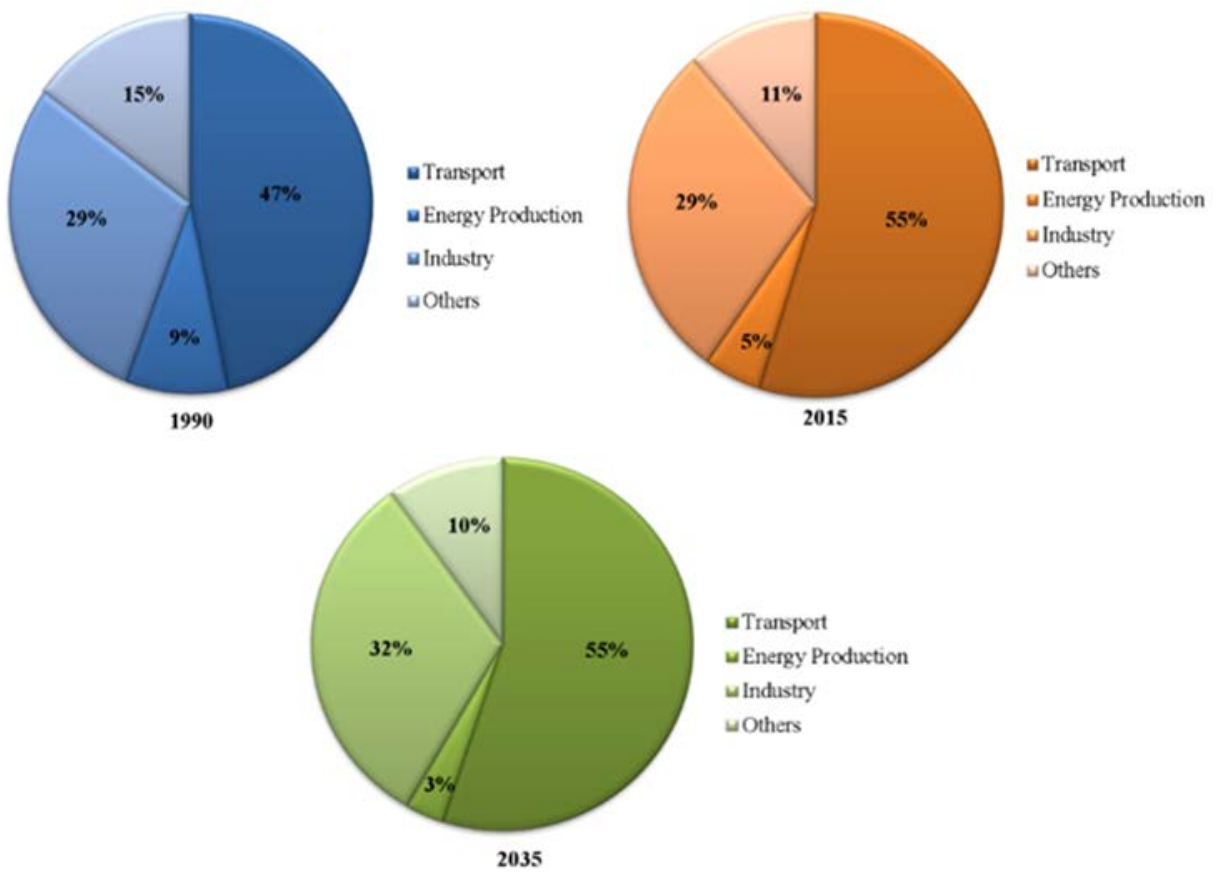

Figure 2: Oil consumption by sectors (based on data from BP [21], [22]).

The fuel combustion by transport causes significant damage to the environment, both from pollution by toxic substances and from $\mathrm{CO}_{2}$ emissions [6], [7].

Carbon dioxide is the main component of technogenic emissions entering the atmosphere when burning organic fuels, thus being an indicator of the scarce hydrocarbon fuels consumption and the level of civilization development as a whole. The increase of $\mathrm{CO}_{2}$ emission contributes to global warming and indicates the depletion of fuel and energy resources. 
In the structure of $\mathrm{CO}_{2}$ emission from the transport sector, the main contribution is made by cars, light trucks, and passenger cars weighing up to 3.5 tons (43.3\%), as well as by cargo vehicles (22.2\%) (Fig. 3).

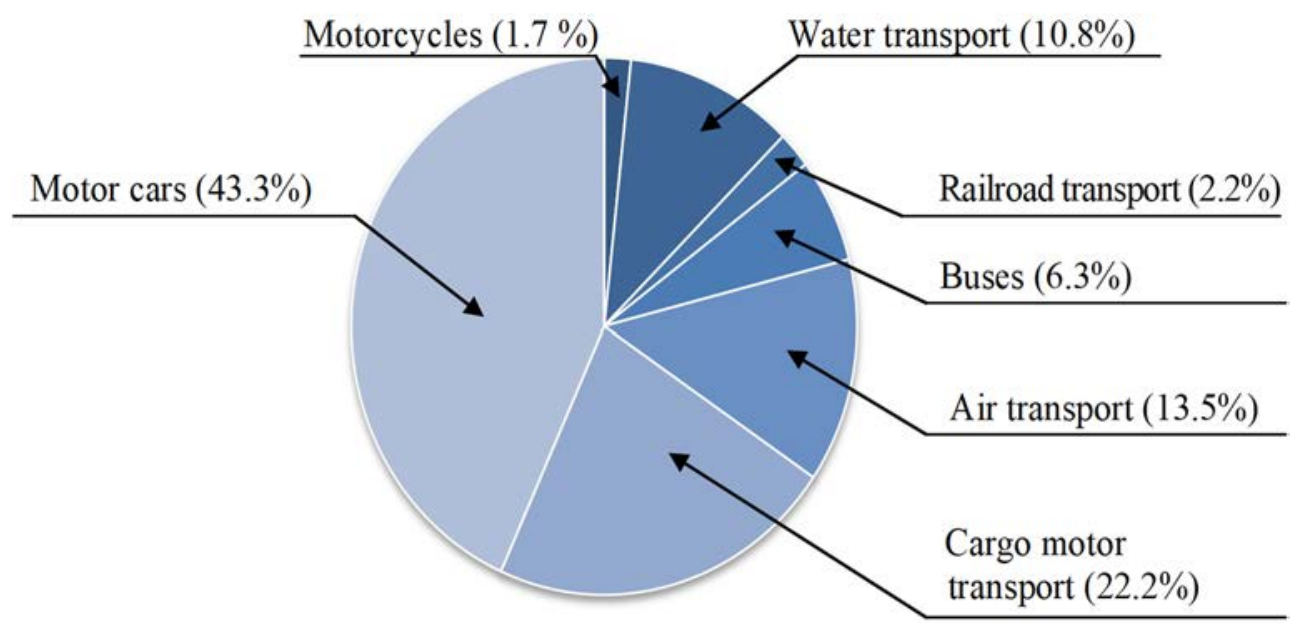

Figure 3: The structure of the world $\mathrm{CO}_{2}$ emission from the vehicle sector of the economy (based on data from BP [20], [21]).

The data in Table 3 show more than a twofold increase in the number of cars in the country during the period of 2000-2017, which was mainly due to passenger cars. Thus, the search for ways to reduce the traditional motor fuels consumption and, accordingly, $\mathrm{CO}_{2}$ emission by cars, is a priority task, the solution to which requires urgent action considering the current high rate of the population motorization [7], [23].

Table 3: The dynamics of the amount of cars in Russia [24], [25].

\begin{tabular}{|l|c|c|c|c|c|c|c|}
\hline \multirow{2}{*}{$№$} & Name & \multicolumn{6}{|c|}{ Years } \\
\cline { 3 - 8 } 1 & $\begin{array}{c}\text { Amount of vehicles, } \\
\text { thousands, } \\
\text { including: }\end{array}$ & $\mathbf{2 5 , 3 9 4}$ & $\mathbf{3 1 , 2 1 0}$ & $\mathbf{4 0 , 6 6 2}$ & $\mathbf{4 5 , 4 7 1}$ & $\mathbf{5 1 , 2 9 0}$ & $\mathbf{5 0 , 6 0 0}$ \\
\hline 1.1 & Passenger cars & 20,353 & 25,570 & 34,354 & 38,792 & 44,200 & 46,500 \\
\hline 1.2 & Trucks & 4,401 & 4,848 & 5,414 & 5,751 & 6,200 & 3,700 \\
\hline 1.3 & Buses & 640 & 792 & 894 & 928 & 890 & 400 \\
\hline
\end{tabular}

\section{THE WAYS OF REDUCING THE PETROLEUM FUELS CONSUMPTION BY ROAD TRANSPORT}

The conducted research allowed us to offer two main ways to reduce the deficit petroleumderived fuel consumption by vehicles: 1) the increase of the fuel economy of cars with gasoline and diesel engines and 2) the use of alternative fuel and energy (Fig. 4) [23], [26], [27]. 


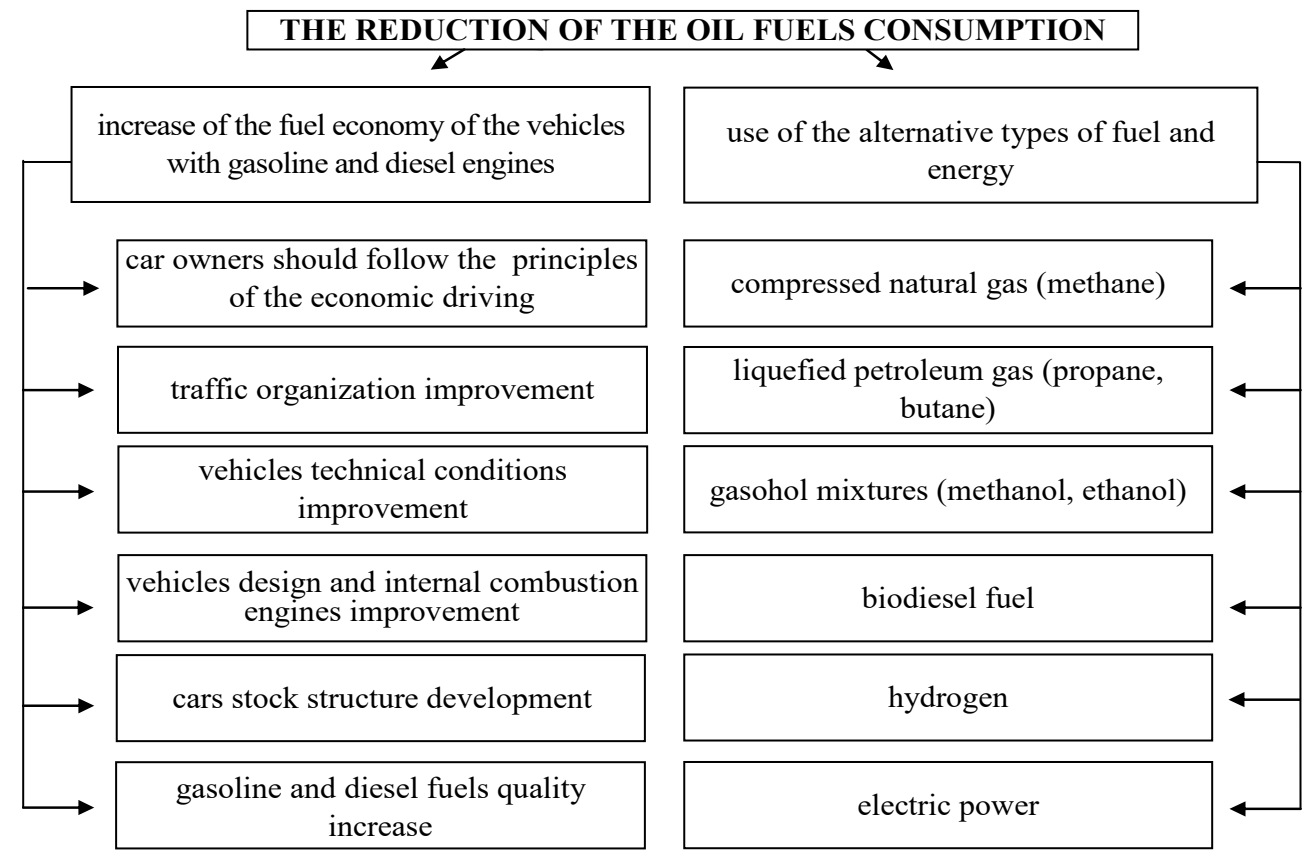

Figure 4: The main ways to reduce petroleum fuels consumption by road transport.

It should be noted that for Russia in the short and medium term, the emphasis should be placed on the quality improvement of traditional motor fuels as one of the most effective ways of increasing vehicle fuel efficiency. One of the possible ways to solve this problem is the effective use of the economic incentive mechanisms of oil products producers, aimed at the improvement of the produced gasoline and diesel fuel environmental characteristics [23], [26]-[29].

The second direction of reducing petroleum fuel consumption by vehicles is the transition to the alternative fuels and energy. It should be underlined that the development of alternative energy in Russia is hampered by a number of objective factors. Russia is rich in traditional fuel and energy resources; as a consequence, the development of alternative energy was not at the forefront.

The raw orientation of the Russian economy extensively exploits traditional energy and hinders the development of alternatives, which requires significant financial resources. The high monopolization of the energy market by the vertically integrated companies is also a serious deterrent to the development of alternative energy in Russia. One cannot ignore the other problems of introducing each type of alternative energy in Russia: financial, geographic (especially climatic), technical, etc.

The change of energy carriers is a painful and long historical period, in which the changes in production technologies are reflected. Meanwhile, the most developed countries at the present stage actively introduce the latest developments in the field of alternative energy. Accordingly, to get the positive results in the matters of alternative energy in the long term, it is necessary to act today. 
Despite the obstacles hampering the development of alternative energy in Russia, there are indisputable prerequisites for an increase in the amount of vehicles using gas-cylinder fuel and other alternative types of motor fuel in the country's total automobile fleet.

The main share of the fuel consumption by the Russian vehicle fleet belongs to gasoline, while this country ranks second in the world (after Iran with their reserves of 34 trillion $\mathrm{m}^{3}$ ) in the field of the prospected proven reserves of natural gas (Table 4) [30], that creates a huge potential for the transition to a highly environmentally friendly gas-cylinder fuel.

Table 4: Characteristics of the natural gas proven reserves and production at the beginning of 2017 (based on data from BP [20], [21]).

\begin{tabular}{|l|c|c|}
\hline Region & $\begin{array}{c}\text { Gas resources, } \\
\text { trillion } \mathbf{~ m}^{\mathbf{3}}\end{array}$ & $\begin{array}{c}\text { The share in the world } \\
\text { resources, \% }\end{array}$ \\
\hline North America & 10.8 & 5.6 \\
\hline Latin America & 8.2 & 4.2 \\
\hline Europe and Eurasia, including: & 62.2 & 32.1 \\
\hline Russian Federation & $\mathbf{3 5 . 0}$ & $\mathbf{1 8 . 1}$ \\
\hline The Near and Middle East & 79.1 & 40.9 \\
\hline Australia and the rest of Asia & 19.3 & 10.0 \\
\hline Africa & 13.8 & 7.1 \\
\hline World, total & $\mathbf{1 9 3 . 5}$ & $\mathbf{1 0 0 . 0}$ \\
\hline
\end{tabular}

As for the electric vehicles and hybrid electric vehicles [31], they are not so relevant for Russia, primarily due to the climatic conditions: the harsh climate in most parts of the country significantly limits their mass use. Also, today, the Russian consumer is not ready to significantly overpay for a car with an environmental performance improvement. The same applies to the vehicles running on biofuel [32]. Under conditions of the large natural gas reserves in Russia, the development of road transport consumption of the other types of alternative energy is only possible in the long term.

\section{THE MAIN PROBLEMS OF THE ALTERNATIVE TYPES OF MOTOR FUEL MARKET DEVELOPMENT AND THEIR SOLUTION}

The main alternative to the petroleum-derived fuels used by Russian transport in the medium term is compressed natural gas (methane) and liquefied petroleum gas (propane-butane mixture) [9], [13]-[17].

Methane is a compressed natural gas supplied to the specialized automobile gas-filling compressor stations (AGSCS) via pipelines. Propane-butane mixture is obtained from oil and condensed petroleum gases. Considering the fact that, firstly, the widespread use of propanebutane as an automotive fuel does not completely abolish dependence on oil; and secondly, our country ranks second in the world in proven prospected reserves of natural gas (Table 4), the use of compressed natural gas is the main alternative to traditional motor fuels. 
Despite the fact that Russia ranks second in the world in proven prospected reserves of the natural gas (Table 4), today it is necessary to solve a number of problems for the widespread introduction of the compressed natural gas as a motor fuel. The main ambitions of the Government in the issue of transport large-scale gasification are registered in the Russian Government decree of May 13th, 2013, № 767-r [33], according to which a set of measures should be developed and submitted so that by 2020 in the subjects of the Russian Federation, the level of natural gas use as a motor fuel by public transport and by municipal services transport would reach $50 \%$ of the total number of the equipment units (in the cities with a population of more than $1,000,000$ people). However, today it is difficult to distinguish the active measures that should be performed by the Government and all the motor fuel market participants to achieve these parameters.

The conducted researches have allowed to reveal the basic problems on a way of the road transport mass gasification in Russia, and also to offer their possible solutions (Figs 5 and 6).

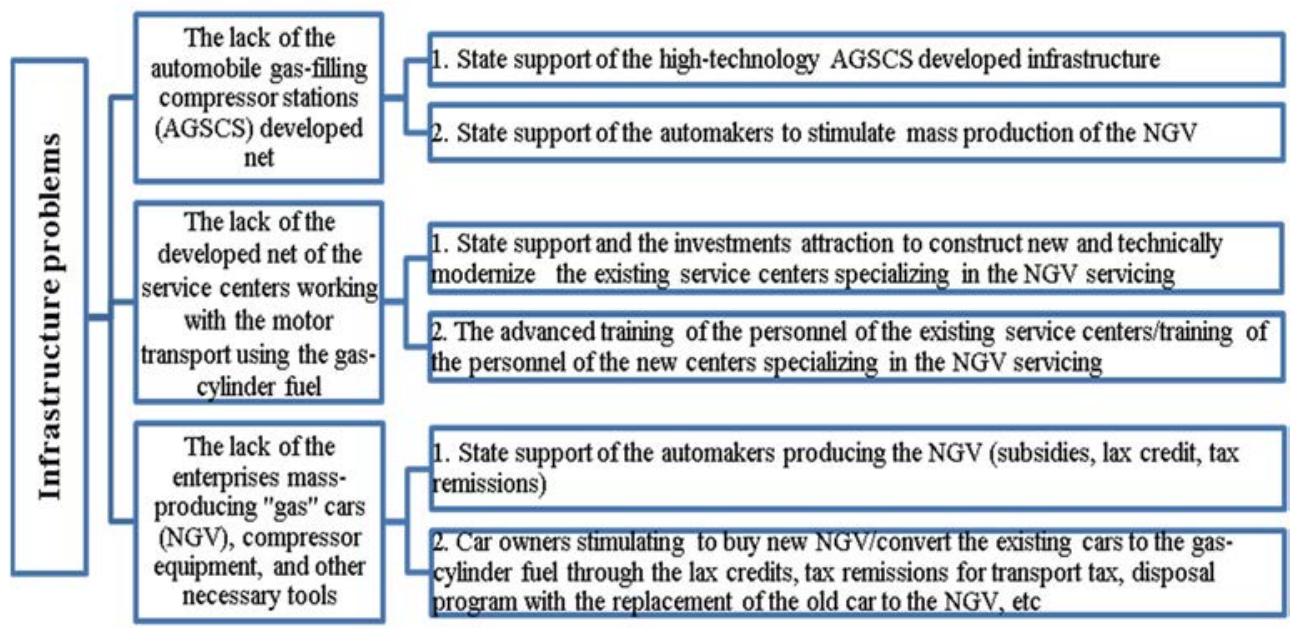

Figure 5: Infrastructure problems of the motor vehicles mass gasification in Russia and ways to solve them.

To date, the infrastructure problems are the major for the mass gasification of transport (Fig. 5). There is not a sufficient number of automobile gas-filling compressor stations (AGSCS) for the large-scale gasification of the car stock. This problem resembles a vicious circle: on the one hand, the development of the gas engine fuel market is hampered by the poorly developed infrastructure, and on the other hand, the infrastructure is absent due to the shortage of natural gas vehicles.

The large-scale gasification of vehicles is a complicated task, requiring a system approach to solve it. In addition to the basic infrastructure problems of this issue, the studies carried out have revealed a number of additional directions for solving the problems of vehicle gasification (Fig. 6).

It is important to note that the transfer of public transport (city buses, fixed-route taxis) to gas, subject to all safety requirements, will lead to a much greater environmental and economic effect than the transfer of the personal vehicles, due to the higher energy efficiency of the trip per passenger. 


\begin{tabular}{|c|c|c|}
\hline \multirow{2}{*}{ 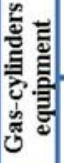 } & $\begin{array}{l}\text { Problematic engine starting under } \\
\text { the low temperature }\end{array}$ & $\begin{array}{l}\text { The development and introduction of the new technological solutions } \\
\text { to eliminate this problem within the framework of a large-scale R\&D }\end{array}$ \\
\hline & $\begin{array}{l}\text { The decrease of the engine power } \\
\text { after conversion to gas-cylinder }\end{array}$ & $\begin{array}{l}\text { The development of the new technological solutions with the } \\
\text { subsequent mass production of the high-technology injection systems } \\
\text { providing the necessary technical and operational indicators }\end{array}$ \\
\hline \multirow{5}{*}{ 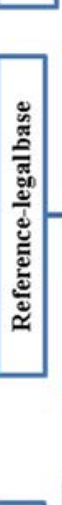 } & $\begin{array}{l}\text { Obsolete reference-legal base } \\
\text { regulating the natural gas vehicles } \\
\text { (NGV) servicing and operation, } \\
\text { and AGSCS construction }\end{array}$ & $\begin{array}{l}\text { To develop and approve new / actualize existing legislative and } \\
\text { regulatory acts regulating the sphere of the gas engine fuel } \\
\text { (construction and operation of AGSCS; maintenance and operation of } \\
\text { the NGV; production of the NGV, etc. }\end{array}$ \\
\hline & $\begin{array}{c}\text { The lack of the specific requirements } \\
\text { to the calculation and approval of the } \\
\text { tariffs for the passengers and cargo } \\
\text { transporting by NGV }\end{array}$ & $\begin{array}{l}\text { To introduce changes in the methods for calculating and approving } \\
\text { tariffs for the passengers and cargo transportation by the NGV }\end{array}$ \\
\hline & $\begin{array}{l}\text { The lack of the gas motors market } \\
\text { development integrated program }\end{array}$ & $\begin{array}{l}\text { The development and approval of a comprehensive long-term program } \\
\text { for the gas-engine market development taking into account the } \\
\text { interests of all its participants }\end{array}$ \\
\hline & $\begin{array}{l}\text { The lack of the State tight control } \\
\text { of the illegitimate and unjustified } \\
\text { prices on the motor fuel market }\end{array}$ & $\begin{array}{l}\text { The tight control by the Federal Antimonopoly Service (FAS) for the } \\
\text { pricing in the car motor fuel market }\end{array}$ \\
\hline & $\begin{array}{l}\text { The lack of the transport tax } \\
\text { incentive rate }\end{array}$ & $\begin{array}{l}\text { Approval of the transport tax preferential rates for the owners of the NGV } \\
\text { and the auto enterprises, converting their car stock to operate on gas fuel }\end{array}$ \\
\hline \multirow{4}{*}{ | } & $\begin{array}{l}\text { The lack of the benefits for the } \\
\text { purchasing of the imported } \\
\text { equipment for the transport } \\
\text { gasification }\end{array}$ & $\begin{array}{l}\text { Reduction of the customs duties on the imported equipment necessary } \\
\text { for the construction of AGSCS and installation of gas-cylinder } \\
\text { equipment on cars }\end{array}$ \\
\hline & \multirow{2}{*}{$\begin{array}{l}\text { The lack of the stimulating } \\
\text { measures for the regions converting } \\
\text { the public transport and the } \\
\text { municipal services transport to the } \\
\text { gas fuel }\end{array}$} & $\begin{array}{l}\text { 1. Granting subsidies to the regional authorities to convert the existing } \\
\text { stock of the public transport and the municipal services transport to gas } \\
\text { fuel and purchasing the new equipment }\end{array}$ \\
\hline & & $\begin{array}{l}\text { 2. To include the level of the natural gas use as a motor fuel in public } \\
\text { transport and municipal services transport (in \% to the total amount of } \\
\text { the equipment units) into the regions heads performance indicators }\end{array}$ \\
\hline & $\begin{array}{l}\text { The lack of the investors } \\
\text { stimulation }\end{array}$ & $\begin{array}{l}\text { Provision of tax credits and other possible preferences to the investors } \\
\text { investing in the gas-cylinder motor fuel market development }\end{array}$ \\
\hline
\end{tabular}

Figure 6: The complex of the additional problems of the vehicles mass gasification in Russia and their solution.

To implement the "modal shift", it is necessary to stimulate the population to abandon a personal car in favour of public transport. To solve this problem, a well-developed infrastructure of public transport is needed, employing the increase in the traffic frequency and the number of vehicles, the increase in the routes number, the improvement of the transport comfort, and its speed increase.

The consumption of gas fuel, taking into account the significant disposable reserves of the natural gas, the potential of the associated petroleum gas processing, and the complex environmental situation in Russia, should increase. The development of the gas-cylinder fuel market in the country is possible only with substantial state support. The significant dependence of vehicle gasification level on State support is evidenced by the accumulated experience of the countries actively developing in this direction.

Considering the high complexity of solving the problem of the significant share of replacing traditional non-renewable energy resources with new sources of energy in the motor transport sector of Russia, it is necessary to integrate the efforts of all the participants in this matter: the scientists, the government, the society, the automakers, and the fuel producers to resolve it. 


\section{CONCLUSION}

In Russia, under the existing conditions of the country's high rate of vehicle-amount growth and the reduction of oil reserves, it is necessary to implement a set of measures to improve the fuel efficiency of vehicles with gasoline and diesel engines, as well as to develop alternative motor fuels. Taking into account the high level of natural gas reserves in the Russian Federation, there is a huge potential for switching to the highly ecological gascylinder fuel. An integrated solution of the main problems of vehicle gasification by the selected directions will allow a reduction of scarce fuel and energy resources consumption, reducing air pollution and improving the ecological situation in the country.

\section{ACKNOWLEDGEMENT}

This research was supported by Act 211 Government of the Russian Federation, contract № 02.A03.21.0006.

\section{REFERENCES}

[1] Schiavon, M. et al., Assessing the air quality impact of nitrogen oxides and benzene from road traffic and domestic heating and the associated cancer risk in an urban area of Verona (Italy). Atmospheric Environment, 120, pp. 234-243, 2015.

[2] Golubeva, A., Magaril, E., Magaril, R., Panepinto, D \& Viggiano, F., Managing the environmental adaptation of vehicles operation. WIT Transactions on Ecology and the Environment, vol. 223, WIT Press: Southampton and Boston, pp. 161-169, 2017.

[3] Yambyshev, F.D. \& Shigabutdinov, R.M., Investigating the pollution of the atmosphere by motor transport. International Journal of Engineering and Technology, 7, pp. 231-234, 2017.

[4] Magaril, E., Increasing the efficiency and environmental safety of vehicle operation through improvement of fuel quality. International Journal of Sustainable Development and Planning, 10(6), pp. 880-893, 2015.

[5] Magaril, E., Improvement of the environmental and operational characteristics of vehicles through decreasing the motor fuel density. Environmental Science and Pollution Research, 23(7), pp. 6793-6802, 2016.

[6] Anisimov, I., Ivanov, A., Chikishev, E., Chainikov, D. \& Reznik, L., Assessment of gas cylinder vehicles adaptability for operation at low ambient temperature conditions. WIT Transactions on Ecology and the Environment, 190(1), pp. 685-695, 2014.

[7] Trofimenko, Y.V., Grigoreva, T.Y. \& Evgenev, G.I., Energy-saving problems of road facilities in Russia. WIT Transactions on Ecology and the Environment, vol. 190, WIT Press: Southampton and Boston, pp. 535-542, 2014.

[8] Magaril, E., Magaril, R., Al-Kayiem, H.H., Skvortsova, E., Anisimov, I. \& Rada, E.C., Investigation on the possibility of increasing the environmental safety and fuel efficiency of vehicles by means of gasoline nano-additive. Sustainability, 11(7), 2019.

[9] Raslavičius, L., Keršysa, A., Mockus, S., Keršienè, N. \& Starevičius, M., Liquefied petroleum gas (LPG) as a medium-term option in the transition to sustainable fuels and transport. Renewable and Sustainable Energy Reviews, 32, pp. 513-525, 2014.

[10] Johnson, E., LPG: a secure, cleaner transport fuel? A policy recommendation for Europe. Energy Policy, 31, pp. 1573-1577, 2003.

[11] Masi, M., Experimental analysis on a spark ignition petrol engine fuelled with LPG (liquefied petroleum gas). Energy, 41, pp. 252-260, 2012.

[12] Streimikiene, D., Baležentis, T. \& Baležentienė, L., Comparative assessment of road transport technologies. Renewable and Sustainable Energy Reviews, 20, pp. 611-618, 2013. 
[13] MacLean, H.L. \& Lave, L.B., Evaluating automobile fuel/propulsion system technologies. Progress in Energy and Combustion Science, 29(2003), pp. 1-69, 2003.

[14] Frick, M., Axhausen, K.W., Carle, G. \& Wokaun, A., Optimization of the distribution of compressed natural gas (CNG) refueling stations: Swiss case studies. Transportation Research Part D: Transport and Environment, 12, pp. 10-22, 2007.

[15] Hekkert, M.P., Hendriks, F.H.J.F., Faaij, A.P.C. \& Neelis, M.L., Natural gas as an alternative to crude oil in automotive fuel chains well-to-wheel analysis and transition strategy development. Energy Policy, 33, pp. 579-594, 2005.

[16] Aslam, M.U., Masjuki, H.H., Kalam, M.A., Abdesselam, H., Mahlia, T.M.I. \& Amalina, M.A., An experimental investigation of $\mathrm{CNG}$ as an alternative fuel for a retrofitted gasoline vehicle. Fuel, 85, pp. 717-724, 2006.

[17] De Carvalho Jr., A.V., Natural gas and other alternative fuels for transportation purposes. Energy, 10, pp. 187-215, 1985.

[18] United Nations (UN), World population prospects: The 2015 revision, key findings and advance tables. UN report, p. 1, 2015.

[19] UN, Department of Economic and Social Affairs website. www.un.org/development/desa/en/.

[20] British Petroleum (BP), Investor tools. http://tools.bp.com/energy-chartingtool.aspx\#/st/carbon/dt/emissions/unit/MTCO2/region/NOA/SCA/EU/MIE/AFR/AP/ view/map/.

[21] BP, Statistical review of world energy. www.bp.com/en/global/corporate/energyeconomics/statistical-review-of-world-energy/downloads.html.

[22] BP, Energy outlook 2035. www.bp.com/en/global/corporate/energy-economics/ energy-outlook-2035.html.

[23] Golubeva, A. \& Magaril, E., Improved economic stimulation mechanism to reduce vehicle $\mathrm{CO}_{2}$ emissions. WIT Transactions on the Built Environment, vol. 130, WIT Press: Southampton and Boston, pp. 485-489, 2013.

[24] Federal State Statistics Service, www.gks.ru.

[25] RIA Novosti, The number of cars in Russia exceeded 56 million, 2016. http://ria.ru/society/20160220/1377940767.html.

[26] Golubeva, A. \& Magaril, E., Economic stimulation to decrease the $\mathrm{CO}_{2}$ emission by the motor transport, UrFU Bulletin. Economy and Management Series, 15(3) pp. 359381, 2016. (In Russian.)

[27] Golubeva, A. \& Magaril, E., Environmental tax as an instrument of economic stimulation to improve the quality of motor fuels. WIT Transactions on Ecology and the Environment, vol. 192, WIT Press: Southampton and Boston, pp. 149-159, 2015.

[28] Mayburov, I. \& Leontyeva, Y., Transport tax in Russia as a promising tool for the reduction of airborne emissions and the development of the road network. WIT Transactions on Ecology and the Environment, vol. 198, WIT Press: Southampton and Boston, pp. 391-401, 2015.

[29] Mayburov, I. \& Leontyeva, Y., Reducing the negative impact of motor transport on the environment: Prospects for the use of fiscal instruments in Russia. WIT Transactions on Ecology and the Environment, vol. 186, WIT Press: Southampton and Boston, pp. 863-874, 2014.

[30] Magaril, E.R., Abrzhina, L.L. \& Golubeva, A.S., Ecological and economic problems and prospects of using the fuel and energy resources. UrFU Bulletin. Series: Economy and management, vol. 5, pp. 114-130. (In Russian.)

[31] Huang, Y., Surawski, N.C., Organ, B., Zhou, J.L., Tang, O.H.H. \& Chan, E.F.C., Fuel consumption and emissions performance under real driving: Comparison between 
hybrid and conventional vehicles. Science of the Total Environment 2019, 659, pp. 275-282.

[32] Al-Kayiem, H.H., Wahhab, H.A.A., Magaril, E. \& Aziz, A.R.A., Performance and emissions investigation of a single cylinder diesel engine using enhanced blend biodiesel by nanoparticles. AIP Conference Proceedings 2018, 2035, 2018.

[33] Garant, Russian Government decree of May 13th, 2013, № 767-r on the regulation of the relations in the sphere of the gas motor fuel use, including natural gas, as a motor fuel. http://base.garant.ru/70376264/\#ixzz4bNyL5R1x. Accessed on: 22 Jun. 2018. 